UDK 502.51(282)(210.7):911.5(282.247.32)

Original scientific paper / Izvorni znanstveni članak

\title{
The Landscape Structure of the Dnipro River Islands in Kyiv, Ukraine: the Venetsiansky (Hydropark) Island Case Study
}

\author{
Anastasiia-Olena POZHARSKA - Kyiv ${ }^{1}$
}

\begin{abstract}
The article studies the Venetsiansky (Hydropark) Island (the Dnipro River, Kyiv, Ukraine) landscape structure applying the genetic landscape science method and the European landscape classification (LANMAP) approach. The river islands being the part of the landscape and the riverscape are the unusual object of the landscape study. The aim of the article is to determine the best way to study the river islands landscapes analyzing the Venetsiansky Island landscape structure by the both methods. The genetic landscape science method consists in the next steps: 1) the island's territory information collecting; 2) the preliminary landscape map creating (based on the remote sensing data); 3) field study; 4) the final landscape map creating. The LANMAP method consists on: 1) the climate study; 2) the altitude study; 3) the parent material study; 4) the land cover/land use study. The genetic landscape science method demonstrates that the Venetsiansky Island is not a landscape, but a structural part of the landscape - the tract (urochyshche). The LANMAP study reveals that the Venetsiansky Island is naturally homogeneous, but land cover differs. The both methods' study shows that the river island cannot be the entire landscape by the natural criteria, but only the part of it. The genetic landscape science explores the landscape forming while the LANMAP reveals the current state of the landscape. The best way is to apply the LANMAP method for the fast preliminary study of the hard-to-reach or, vice versa, anthropogenic affected river islands and to apply the genetic landscape science method for the more detailed examination of the river islands.
\end{abstract}

Keywords: the landscape structure, the river island, the Venetsiansky (Hydropark) Island, the genetic landscape study, the European Landscape Classification (LANMAP).

\footnotetext{
${ }^{1}$ Anastasiia-Olena Pozharska, PhD candidate, Faculty of Geography, Taras Shevchenko National University of Kyiv, Akademika Hlushkova Avenue 2, UA-02017 Kyiv, Ukraine, e-mail: pozharska1@ukr.net
} 


\section{Introduction}

The river islands are the specific object of the study: they are both the part of the landscape and the riverscape. The scientists explore mainly the flora and the fauna, the forming and evolving features (Pozharska 2020). The landscape study of the river islands provide the following trends: the Russian scientists explore the river islands as the part of the floodplain and apple the genetic landscape study method (for instance, the Sarpinskij island study (the Volgograd city, the Volga river, Russia)) (Prokazov 2011, Rulev et al. 2017). The other popular method is the European landscape classification.

The Dnipro River is one of the largest European rivers. Flowing Kyiv it forms the quite large islands on its territory: the Trukhaniv, the Venetsiansky, the Dolobetsky islands. Some of them reserve the rare flora and fauna species (Parnikoza 2012). The scientists study these islands' landscapes mostly as the part of the Kyiv's landscapes. Therefore the following papers are generalized and fragmentary, often outdated. The most studied is the Venetsiansky Island. But there is no landscape study dedicated to this island. Therefore the landscape study of the Dnipro River islands in Kyiv is needed taking into account the latest trends in the landscape study.

This article aims to create the landscape map of the Venetsiansky Island using the genetic and the LANMAP methods and to identify the most attractive one.

\section{Theoretical Background}

The genetic theory author is Solntsev. According to his meaning the main landscape study object is a landscape - the genetically homogeneous natural territorial complex with the same geological foundation, the same type of relief, the same climate, and consisting of an unique combination of dynamically conjugates and regularly repeated in space primary and secondary tracts (Annenskaja et al. 1962). Solntsev and his followers (Annenskaja et al. 1962, 1963, Vidina 1963) developed the landscape research methodology in the large scale. Nikolaev (1963) proposed the floodplain landscape study method. The method of the landscape identification applied by the Solntsev's followers can be called the genetic method.

According the genetic landscape study the landscape consists of the tracts the natural territorial complexes, which consist of regularly combination of so-called undertracts and facies, which are usually combined with mesorelief form and therefore have a strong genetic unity and dynamic conjugation. The tract is usually clearly allocated in space. Sometimes the tracts can be united into the larger unites - the districts. The parts of the tract are facies - a natural territorial complex, the entire area of which retains the same lithology of surface rocks, the same nature of relief and moisture, one microclimate, one soil separation, one biocenosis (Annenskaja et al. 1962, 1963, Vidina 1963).

The structural-genetic landscape study consists of the three steps: the prelimi- 
nary study, the field study and the office study.

At the preliminary study the maximum data is collected: the geological, geomorphological, hydrological, soil and vegetation maps and plans of the territory. The remote sensing (aerial and space) data (in scale 1:10000 - 1:17000) analysis founds the preliminary landscape map.

The next step is the field study. A network of the routes and observation points on the preliminary map is selected. During the field phase the researcher make the reconnaissance of the territory. The relief, the parent material, the soils and the vegetation study on the determined points name the natural territorial complexes. The result of the field study is the field landscape map.

At the office study the final landscape map is made according to the preliminary and the field research.

The methodology of the European landscape classification was elaborated in the XXI century by Mücher and his colleagues (Mücher et al. 2010). According to this methodology the landscapes are resulted from long-term interactions of natural abiotic, biotic and anthropogenic processes. Landscapes are regarded as forming recognizable parts of the earth's surface and as showing a characteristic ordering of elements (Mücher et al. 2010). For convenience the method used by Mücher and his colleagues can be called the LANMAP method.

According to the LANMAP theory the landscape is by the four main factors formed: the climate, the relief, the parent material and the land use. In obedience to the factors the four hierarchical levels are defined. The researcher uses the digital data on climate, altitude, parent material and land use and according to this factors define the landscape. The climate can be determined be the European Environmental Stratification (Metzger et al. 2005) and the Biogeographical Regions Map of Europe (Roekaerts 2002). The altitude can be defined by the European Soil Database (CEC 1985) and the FAO Soil Map of the World (FAO 1991). Due to the lack or low quality of soil data, data on the parent breed can be used. The land use/land cover data can be taken from the next interactive data bases: CORINE (CEC 1994, Nuñes de Lima 2005), GLC2000 (Bartholomé and Belward 2005) and PELCOM (Mücher et al. 2000, 2001).

\section{Data and Methods}

The methods of genetic landscape study and the LANMAP method were used to create a large-scale landscape map.

1. Creating a landscape map by the method of genetic landscape study.

1.1. The preliminary step.

The existing data on the Venetsiansky Island contains:

- the soil map (Bortnyk et al. 2016),

- the map of the landscape-architectural complexes (Dmytruk et al. 2011),

- the candidate's dissertation of Savytska (2003),

- the Dmytruk's monograph (1998), 
- the Parnikoza's monograph (2012),

- the report (1980) and the monograph (1983) of Galytskyj, Davydchuk, Shevchenko,

- the candidate's dissertation of Tsukanova (2005),

- the Klymenko's article (1999).

This data suggest that tectonically the Dnipro valley (and, accordingly, the Venetsiansky Island) lies in the fault among the Ukrainian crystal shield and the Dnipro-Donetsk depression (Galytskyj et al. 1980). The parent material is the modern alluvial deposits lying close to the surface $(0.3-0.6 \mathrm{~m})$. The relief is slightly waving with insignificant height differences (absolute heights $-90-100 \mathrm{~m})$.


\section{Legend}

$\square<=91.4836$

$91.4836-92.5432$

$92.5432-93.6028$

$93.6028-94.6624$

$94.6624-95.722$

$95.722-96.7816$

$96.7816-97.8412$

$97.8412-98.9008$

$98.9008-99.9604$

$>99.9604$

Units of mesure - meters above sea level

Fig. 1. The DEM of the Venetsiansky Island (source: the DEM of Kyiv).

The river Dnipro strongly influences the island. The microclimate of the island corresponds to the Kyiv's suburbs climate. The soils are identified as alluvial turfy or floodplain soils. In vegetation the restored poplar-oak forests dominate.

Data from the Bing Aerial service were used to create a preliminary map of the natural territorial complexes. The following natural territorial complexes can be distinguished by the tone, structure and color of the image: 
- coastal white stripes - beaches,

- dense coarse-grained dark green image - woody vegetation,

- light green fine-grained - meadow vegetation,

- mixing of coarse-grained dark green and fine-grained light green image mixing of meadow and woody vegetation.

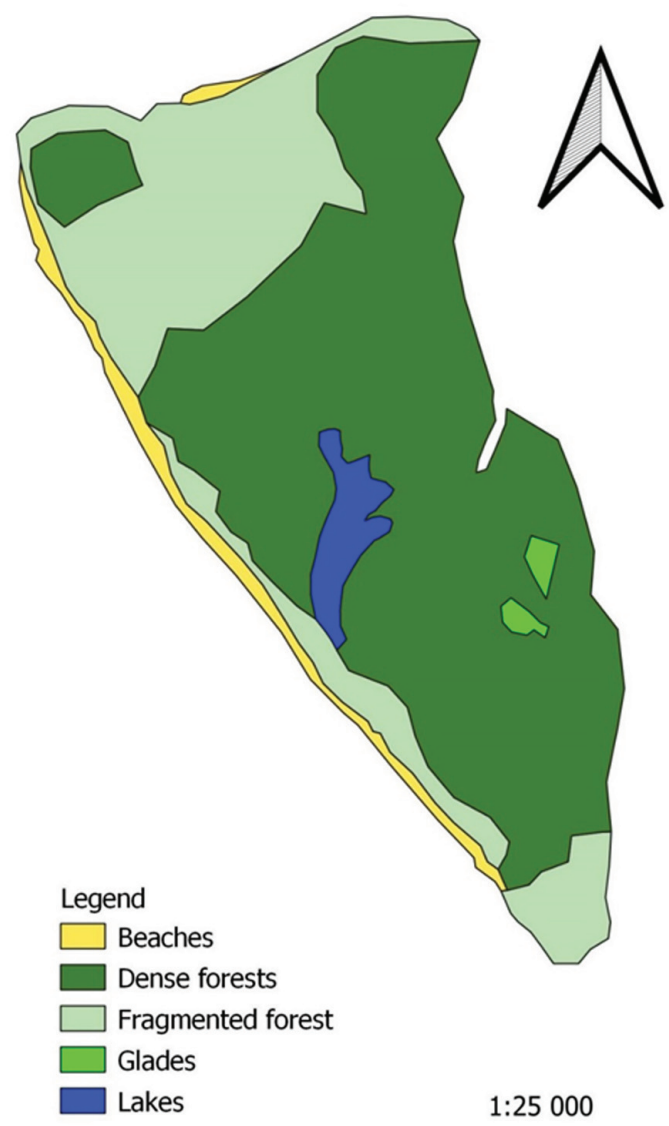

Fig. 2. The preliminary map of the natural territorial complexes of the Venetsiansky Island (source: author development).

1.2. The field study, the field map creating.

To clarify the natural complexes data the seventh-point route was paved.

The point 1 was located in the southwestern part of the island with a mixed coarse-grained dark green and fine-grained light green image. It was found that in this area the fragmented forests are caused by the anthropogenic activity.

The point 2 is located in the central part of the Venetsiansky Island depicted as 
a thick dark green background on the satellite images. This part of the island is grown by the mixed oak-poplar-maple forests with Virginia creeper (Parthenocíssus quinquefolia) and nettle (Urtica dioica) undergrowth.

The point 3 is located in the center of the island in the area with the meadow vegetation.

The point 4 is located in the pine-oak forest.

The point 5 is located near the south-eastern coast of the Berizka Lake, situated in the center of the Venetsiansky Island. The shores of the lake are grown be the hydrophytic vegetation.

The point 6 is located in the fragmented forest near the southwestern coast with tree vegetation of Norway maple, poplar white and black. The undergrowth and the grass were destroyed be the tourists.

The point 7 is located on the sand beach forest near the southwestern coast of the Venetsiansky Island, where there is no permanent vegetation.

The field study data contributed to the field landscape map creation:

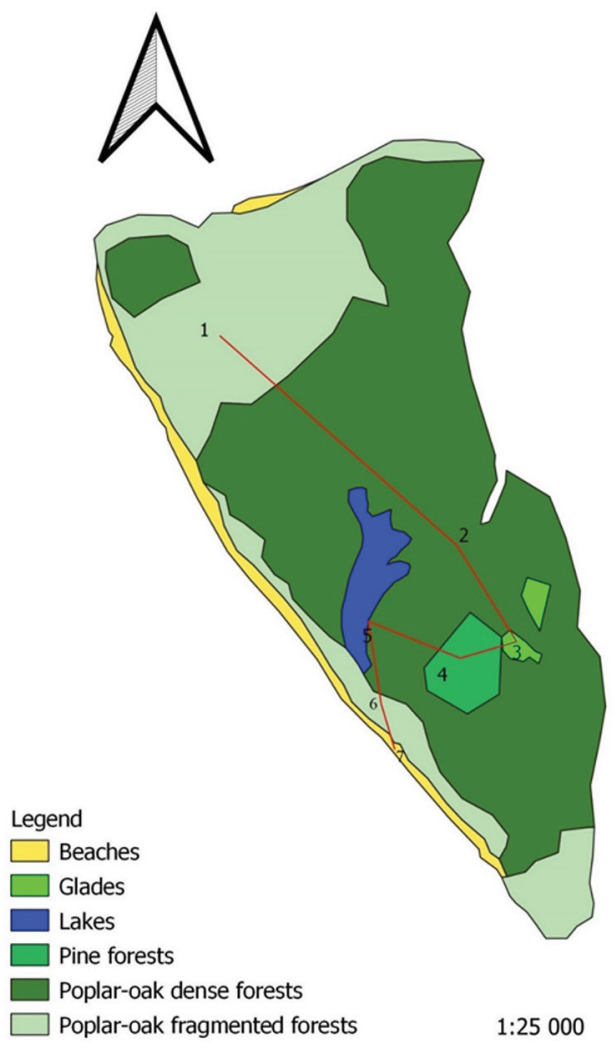

Fig. 3. The field landscape map of the natural territorial complexes of the Venetsiansky Island (source: author development). 
1.3. The final landscape map creation.

According to the preliminary and the office study the final landscape map of the Venetsiansky Island was created:

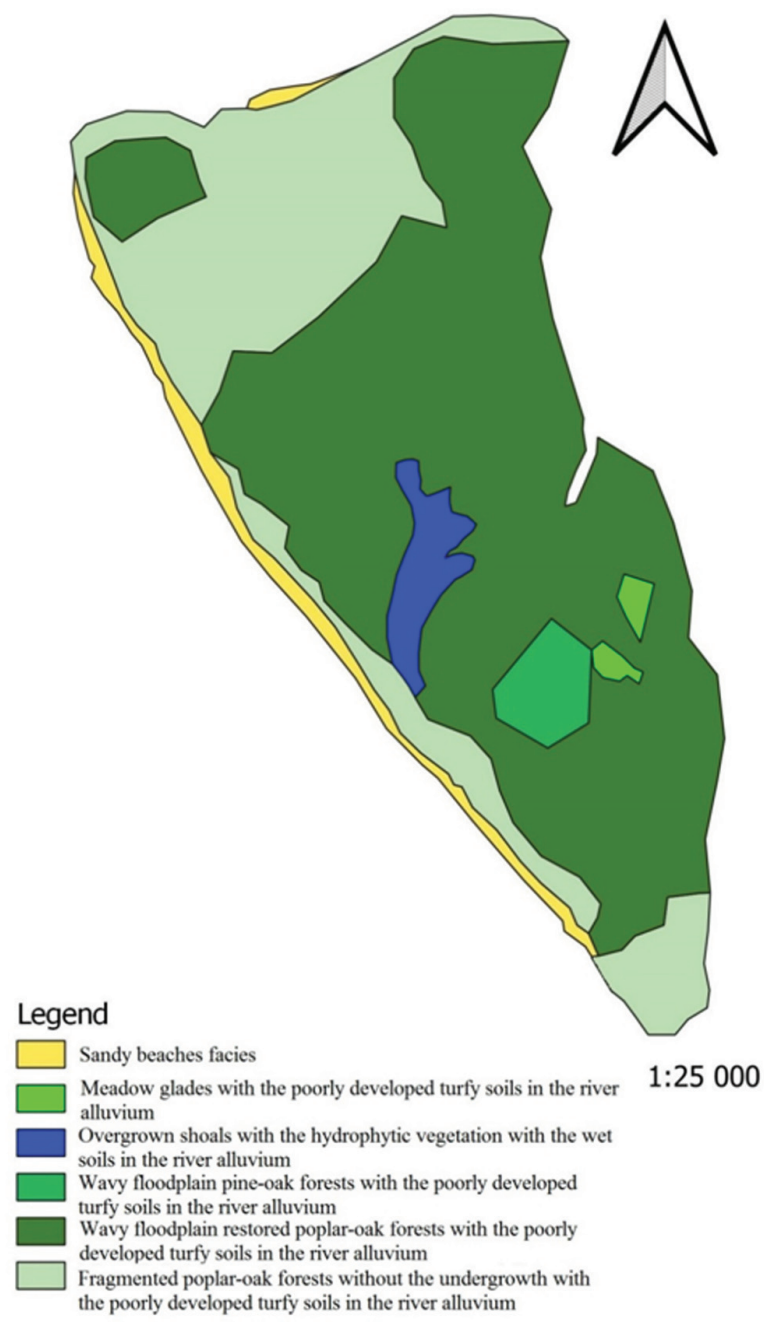

Fig. 4. The final landscape map of the natural territorial complexes of the Venetsiansky Island (source: author development).

2. Creating a landscape map using the LANMAP method.

2.1. The climate.

According to European Environmental Stratification (Metzger et al. 2005) and the Biogeographical Regions Map of Europe the Venetsiansky Island is located in the continental climate zone. 
2.2. The relief.

Due to the Digital Elevation Model (URL 1) the Venetsiansky Island belongs to the lowlands with elevation of 50-100 m above the sea level. According to the class of the relief the Venetsiansky Island is flat to undulating (dominant slopes between 0 and $8 \%$ gradient slope).

2.3. The soils.

According to the European Soil Database and the FAO Soil Map of the World the Venetsiansky Island is covered with rich fluvisols (Je) - soil of the modern alluvial deposits.

2.4. The land cover/land use.

Due to the CORINE database (https://land.copernicus.eu/pan-european/corineland-cover/clc2018/\#), the Venetsiansky Island contains beaches, water bodies, roads, sport and leisure facilities, broad-leaved forests, coniferous forests.

Using the LANMAP method the landscape map was created:

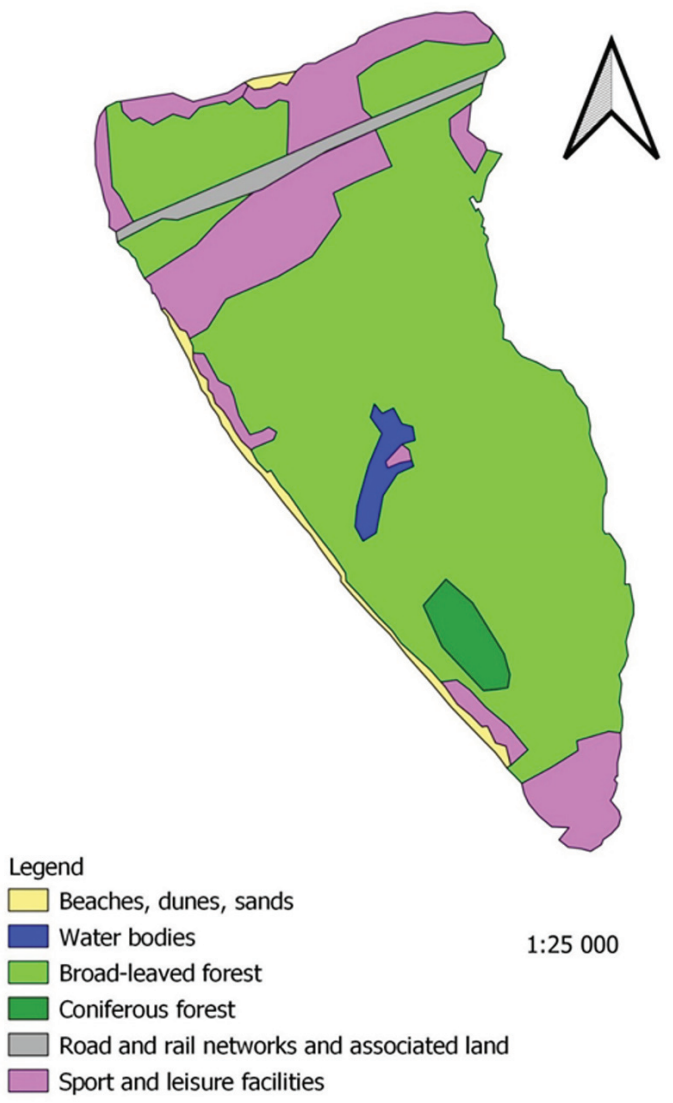

Fig. 5. The landscape map of the Venetsiansky Island (LANMAP) (source: author development). 


\section{Results}



Fig. 6. The maps compiled with different methods: with genetic method (to the left) and with LANMAP method (to the right).

Due to the created landscape maps data the following conclusions can be made about the landscape structure of the Venetsiansky Island:

1. The landscape structure of the Venetsiansky Island (the genetic landscape study):

The Venetsiansky Island is clearly outlined by the Dnipro river water and occupies the one mesoform of the relief, therefore is the tract. The Venetsiansky Island tract is complicated and contains two undertracts: the coastal sandy alluvial beaches undertract with no permanent soil and vegetation cover and the floodplain restored poplar-oak forests undertract.

The coastal sandy alluvial beaches undertract is simple and contains the sandy beaches facies.

The floodplain restored poplar-oak forests undertract is complicated and consists on the next facies:

- the facies of wavy floodplain restored poplar-oak forests with the poorly developed turfy soils in the river alluvium,

- the facies of the wavy floodplain pine-oak forests with the poorly developed turfy soils in the river alluvium,

- the facies of the fragmented poplar-oak forests without the undergrowth with the poorly developed turfy soils in the river alluvium, 
- the facies of the meadow glades with the poorly developed turfy soils in the river alluvium,

- the facies of the overgrown shoals with the hydrophytic vegetation with the wet soils in the river alluvium.

2. The landscape structure of the Venetsiansky Island.

Regarding the LANMAP classification, the Venetsiansky Island is homogeneous according to the all natural criteria (climate, altitude, parent material). However, due to the land use, landscapes of the beaches, water bodies, roads, sport and leisure facilities, broad-leaved forests, coniferous forests can be distinguished.

\section{Discussion}

The LANMAP classification is essentially typological. It divides the Earth into the certain types of the landscapes forming in the certain conditions. The classification proceeds "from top to bottom": from the largest taxonomic unis to the smallest. According to this classification in the territorially separated locations within the same climate, altitude, parent material and land use characteristics, the same landscapes are formed. This classification was conceived for the European region, respectively, operates in the relatively large territorial units. The proper landscape is the final product of the classification; there are no smaller territorial units. The considerable attention is paid to the economic use of the territory. In fact, at the lowest hierarchical level, the anthropogenic changes are a decisive factor in the landscape allocation.

The genetic landscape study distinguishes the landscape units "from bottom to top": from the smallest to the largest. The genetic landscape science aims to find out the natural factors of the landscape differentiation. The anthropogenic variability of the territory is taken into account as a landscape differentiation factor into the natural (native) and altered (derivative). The landscape morphological parts distinguishing criteria are subjective, so the landscape distinction is in fact the personal opinion of private scientist.

According to landscape differentiation in the genetic landscape study the Venetsiansky Island is too small to be the independent landscape. But the Venetsiansky Island is not the only island composed be the Dnipro river sediments. The following islands are situated on the territory of the Dnipro river floodplain in Kyiv.

Therefore, it is appropriate to talk about the Dnipro floodplain-island landscape formed by the direct influence of the Dnipro River. Galytskyj, Davidchuk and Shevchenko came to a similar conclusion in their monograph (1983). The Dnipro moves from the east to the west undermining the Ukrainian crystal shield on the right bank and leaving the flattening area on the right bank. Thereby the left-bank floodplain is not completely identical to the right-bank floodplain. The Dnipro river islands also differ from the right-bank and the left-bank floodplains. Therefore the right-bank floodplain district, the left-bank floodplain district and the river islands district can be distinguished. Accordingly, the Venetsiansky and other islands in the Dnipro river territory can be called tracts because of their natural distinction in the relief. 


\section{Conclusion}

Applying the genetic landscape study method and the LANMAP method to determine the Venetsiansky Island landscape structure it can be concluded that the both classifications at the level of the natural landscape cover a larger than a river island area. Differentiation into the smaller landscape structures in the LANMAP classification occurs due to the definition of economic use of the territory, and in the classification of genetic landscape - due to the local natural processes.

The genetic method is more complicated to apply because of the non-automatic work's significant number. The time consuming and the resource-intensive field study are needed to conduct. However, this technique helps to understand better the genesis of the landscapes, and, consequently, to predict their future processes.

The LANMAP method is faster, easier and cheaper to find out the current state of the area without deepening into the causal relationships of the natural processes, especially for the remote regions. The genetic method is better to use to the unchanged or little changed by the human activity territories, where the field study are possible. Also is possible to apply the method to the changed by the human activity, abandoned and, thereby, nature restored areas.

The plain river island landscapes are not well-explored in the landscape study. The Venetsiansky Island genetic study proves that, with the high probability, the plain river island is the tract with the inner undertracts and facies differentiation. The group of the islands forms a district, and the whole floodplain area with the islands in a certain geological-geomorphological and climatic region forms a landscape. The same floodplain territory with the islands has the equal natural criteria and forms the landscape according to the LANMAP classification, but differs by the land use.

The genetic and the LANMAP methods application conclude that both of them have the strengths and the weaknesses. For the river island landscape study it needs to combine the strengths of both methods.

\section{References}

Annenskaja, G. N., Vidina, A. A., Zhuchkova, V. K., Konovalenko, V. K., Mamaj, I. I., Pozdneeva, M. I., Smirnova, E. D., Solntsev, N. A., Tseselchuk, Ju. N. (1962): Morfologicheskaja struktura geograficheskogo landshafta (The Morphological Structure of the Geographical Landscape), By Solntsev (ed.), Lomonosov Moscoe State University, Moscow.

Annenskaja, G. N., Vidina, A. A., Zhuchkova, V. K., Konovalenko, V. K., Mamaj, I. I., Pozdneeva, M. I., Smirnova, E. D., Solntsev, N. A., Tseselchuk, Ju. N. (1963): Morfologicheskoe izuchenie geograficheskih landshaftov (The Morphological Study of the Geographical Landscapes), In: Solntsev, N. A. (ed.), Landschaftovedenie, Izdatel'stvo Akademii nauk SSSR, Moscow, $5-28$.

Bartholomé, E., Belward, A. S. (2005): GLC2000: a new approach to global land 
cover mapping from earth observation data, Int. J. Remote Sens., 26(9), 1959-1977.

Bortnyk, S., Lavruk, T., Tymulyak, L. (2016): Gruntovyi pokryv terytorii Kyieva: suchasnyi stan ta zakonomirnosti prostorovoi orhanizatsii (The Soil Cover of the Kyiv City Territory: Current State and Spatial Organization), Physical Geography and Geomorphology, 84(4), 44-49.

CEC (1985): Soil Map of the European Communities 1:1.000.000 (Tavernier, cs), Commission of the European Communities, Luxembourg.

CEC (1994): CORINE Land Cover, Technical Guide, Office for Official Publications of European Communities, Luxembourg.

Ding, D., Jiang, Y., Wu, Y., Shi, T. (2020): Landscape Character Assessment of Water-land Ecotone in an Island Area for Landscape Environment Promotion, Journal of Cleaner Production, 259, 120934.

Dmytruk, O. Yu. (1998): Urbanistychna geohrafiia. Landshaftnyi pidkhid. (Metodyka landshaftnoho analizu urbanizovanykh terytorii) (The Urban Geography. The Landscape Approach (The Landscape Analysis' Methods of the Urban Areas)), Kyiv University, Kyiv.

Dmytruk, O., Olishevska, Yu., Demianenko, S., Kupach, T. (2011): Landshaftnoarkhitekturni kompleksy mista Kyieva (The Landscape-architectural Complexes of Kyiv City), Bulletin of Taras Shevchenko National University of Kyiv, Geography, 58, 23-27.

FAO (1991): The Digitized Soil Map of the World (Release 1.0), Rep. No. 67/1, Food and Agriculture Organization of the United Nations, Rome.

Galitskij, V. I., Davydchuk, V. S., Shevchenko, L. N. (1980): Geograficheskie problem razvitija goroda Kieva i ego prigorodnoj zony: zakljuchitel'nyj otchet, Kniga 2, Prirodnye territorial'nye kompleksy prigorodnoj zony Kieva (The Geographical Problems of the Kiev City and its Suburban Area Development: the Final Report, Book 2, The Natural Territorial Complexes of the Suburban Area of Kiev), Akademia nauk USSR, Kyiv.

Galitskij, V. I., Davydchuk, V. S., Shevchenko, L. N. et al. (1983): Landshafty prigorodnoj zony Kieva i ih racional'noe ispol'zovanie (The Landscapes of the Suburban Area of Kiev and their Rational Use), Naukova dumka, Kyiv.

Klimenko, Yu. A. (1999): Tendentsii zminy derevnoi roslynnosti Kyivskykh parkiv, stvorenykh na bazi roslynnosti zaplavy Dnipra (The Tendencies of Change in Arborescent Plantation of Kyiv Parks Created on the Basis of the Dnieper River Basin Plantations), Plant Introduction, 3-4, 149-156.

Metzger, M. J., Bunce, R. G. H., Jongman, R. H. G., Mücher, C. A., Watkins, J. W. (2005): A climatic stratification of the environment of Europe, Global Ecol. Biogeogr., 14(6), 549-563.

Mücher, C. A., Steinnocher, K. T., Kressler, F. P., Heunks, C. (2000): Land cover characterization and change detection for environmental monitoring of Pan-Europe, Int. J. Remote Sens., 21(6-7), 1159-1181.

Mücher, C. A., Champeaux, J. L., Steinnocher, K. T., Griguolo, S., Wester, K., Heunks, C., Winiwater, W., Kressler, F. P., Goutorbe, J. P., ten Brink, B., van Katwijk, V. F., Furberg, O., Perdigao, V., Nieuwenhuis, G. J. A. (2001): Development of a Consistent Methodology to Derive Land Cover 
Information on a European Scale From Remote Sensing for Environmental Monitoring, The PELCOM Report, Alterra rapport 178/CGI-Report 6, Alterra, Wageningen, the Netherlands.

Mücher, C. A., Klijn, J. A., Wascher, D. M., Schaminée, J. H. J. (2010): A new European Landscape Classification (LANMAP): A transparent, flexible and user-oriented methodology to distinguish landscapes, Ecological Indicators, 10(1), 87-103.

Nikolaev, V. A. (1963): Izuchenie pojmennyh landshaftov po materialam aerofotos'emki (na primere Volgo-Ahtubinskoj pojmy) (The Floodplain Landscapes Study Using the Aerophotography Data (the Volgo-Ahtubinska Floodplain Case Study)), In: Solntsev, N. A. (ed.), Landschaftovedenie, Izdatel'stvo Akademii nauk SSSR, Moscow, 147-154.

Nuñes de Lima, M. V. (ed.) (2005): IMAGE2000 and CLC2000: Products and Methods, European Commission, Joint Research Centre, Ispra, Italy, European Communities, EUR 21757 EN, Italy.

Parnikoza, I. Yu. (2012): Kyivski ostrovy ta pryberezhni urochyshcha na Dnipri - pohliad kriz viky (Kyiv Islands and Coastal Tracts on the Dnipro - through the Ages), Dnipro, Kyiv.

Pozharska,A.-O.Yu.(2020): Richkovi ostrovy u heohrafichnykh doslidzhenniakh (River Islands in the Geographic Research), Ecological Sciences, 31(4), 6165.

Prokazov, M. Yu. (2011): Analiz landshaftnoj differenciacii i problem racional'nogo prirodopol'zovanija na ostrovah severnoj chasti Volgogradskogo vodohranilish a (Landscape Differentiation and Problems of Conservancy Analysis of North Part of Volgograd Storage Pond Islands), Izvestiya of Saratov University, New Series, Series: Earth Sciences, 11(1), $2-12$.

Roekaerts, M. (2002): The Biogeographical Regions Map of Europe, Basic principles of its Creation and Overview of its Development, European Environment Agency, Copenhagen.

Rulev, A. S., Dorohina, Z. P., Kosheleva, O. Ju., Shinkarenko, S. S. (2017): Kartografirovanie landshaftnoj struktury pojmennyh jekosistem nizhnej Volgi (na primere ostrova Sarpinskij) (The Landscape Structure of the Lower Volga Floodplain Ecosystems' Mapping (Sarpinsky Island Case Study)), Science life, 11, 48-56.

Savytska, O. V. (2003): Landshaftno-ekolohichnyi analiz zelenoi zony stolychnoho mista (na prykladi mist Kyieva i Berlina) (The Landscapeecological Analysis of Green Zone of the Capital City (on Example of Kyiv, Ukraine and Berlin, Germany)), Candidate's Thesis, Institute of Geography of National Academy of Sciences of Ukraine, Kyiv.

Tsukanova, G. O. (2005): Florystychne ta tsenotychne riznomanittia ostroviv Dnipra v mezhakh m. Kyieva ta yoho okhorona (Floristic and Cenotic Diversity of the Dnieper Islands within Kyiv and its Protection), Candidate's Thesis, M. G. Kholodny Institute of Botany of the National Academy of Sciences of Ukraine, Kyiv. 
Vidina, A. A. (1963): Metodicheskie voprosy polevogo krupnomasshtabnogo kartografirovanija (The Methodological Issues of the Large-scale Field Mapping), In: Solntsev, N. A. (ed.), Landschaftovedenie, Izdatel'stvo Akademii nauk SSSR, Moscow, 102-127.

URL

URL 1: Digital Elevation Model GTOPO30, https://www.usgs.gov/centers/ eros/science/usgs-eros-archive-digital-elevation-global-30-arc-secondelevation-gtopo30?qt-science_center_objects=0\#qt-science_center_ objects, (4. 6. 2021).

\section{Pejzažna struktura otoka na rijeci Dnjepar u Kijevu, Ukrajina: studija slučaja otoka Venetsiansky (Hydropark)}

SAŽETAK. Članak proučava pejzažnu strukturu otoka Venetsiansky (Hydropark) (rijeka Dnjepar, Kijev, Ukrajina) primjenjujući znanstvenu metodu pejzažne genetike i pristup Europske klasifikacije krajolika (LANMAP). Riječni otoci, kao dio krajolika i riječnog krajolika, neuobičajeni su objekti studije krajolika. Cilj je ovog rada određivanje najboljeg načina proučavanja krajolika riječnih otoka kroz analizu krajolika otoka Venetsiansky koristeći obje metode. Znanstvena metoda pejzažne genetike sastoji se od sljedećih koraka: 1) prikupljanje informacija o teritoriju otoka; 2) preliminarna izrada pejzažne karte (na temelju podataka dobivenih daljinskim istraživanjima); 3) terensko istraživanje; 4) izrada konačne pejzažne karte. Metoda LANMAP sastoji se od: 1) klimatskog proučavanja; 2) proučavanja nadmorske visine; 3) proučavanja osnovnog materijala; 4) proučavanja pokrova/korištenja zemljišta. Znanstvena metoda pejzažne genetike pokazuje da otok Venetsiansky nije krajolik, već strukturni dio krajolika - zemljišna pouršina (urochyshche). Studija LANMAP otkriva da je otok Venetsiansky prirodno homogen, ali se zemljišni pokrov razlikuje. Primjenjujući obje metode, proučavanja pokazuju da riječni otok ne može biti cijeli krajolik po prirodnim kriterijima, već samo njegov dio. Znanost pejzažne genetike istražuje formiranje krajolika, dok LANMAP otkriva trenutno stanje krajolika. Najbolji je način primjena metode LANMAP za preliminarno proučavanje otoka koji su teško pristupačni, odnosno antropogeno zahvaćenih riječnih otoka te primjena znanstvene metode pejzažne genetike u surhu detaljnijeg ispitivanja riječnih otoka.

Ključne riječi: pejzažna struktura, riječni otok, otok Venetsiansky (Hydropark), proučavanje pejzažne genetike, Europska klasifikacija krajolika (LANMAP).

Received / Primljeno: 2021-06-05

Accepted / Prihvaćeno: 2021-12-23 